\title{
Length of Stay: Price and Income Semi-Elasticities at Different Destinations in Italy
}

Luca Salmasi $^{1, *}$, Martina Celidoni ${ }^{2}$ and Isabella Procidano ${ }^{3}$

${ }^{1}$ University of Verona-Department of Economics, Verona, Italy

${ }^{2}$ University of Padua-Department of Economics, Padua, Italy

${ }^{3}$ University of Venice-Department of Economics, Venice, Italy

\section{ABSTRACT}

In this paper, we estimate price and income semi-elasticities of the length of stay at different destinations in Italy using the 'Multipurpose survey on tourism demand, holidays and trips' provided by the Italian National Institute of Statistics (ISTAT). We derive the conditional demand function for the length of stay, which depends on tourists' socio-demographic characteristics, travel characteristics, income and price of touristic services. Since income was not reported in our database, we use the propensity score matching to retrieve this information from the 'Survey on household income and wealth (SHIW)', and we use quantile regression to account for the multimodality of the length of stay. Copyright $@ 2012$ John Wiley \& Sons, Ltd.

Received 11 May 2011; Revised 2 December 2011; Accepted 3 December 2011

Keywords: tourism; length of stay; semielasticity; count quantile regression.

\section{INTRODUCTION}

$\square$ he length of stay is considered one of the major choice variables in a visitor's decision-making process (Decrop and Snelders, 2004); tourists compare the benefits of

${ }^{*}$ Correspondence to: Luca Salmasi, University of VeronaDepartment of Economics, Verona, Italy.

E-mail: luca.salmasi@univr.it different alternatives and assess costs and length of stay, taking into account their financial and time constraint (Alegre and Pou, 2006). However, despite its importance, this variable has received attention in literature only recently. Its economic influence has been described by some studies that highlighted a positive relation between duration and total expenditure; also, shorter stays have been found relevant because of their high daily per capita expenditure (Downward and Lumsdon, 2000; Cannon and Ford 2002; Kastenholz, 2005). Understanding how tourists take decisions also about the duration of the stay is therefore an important economic concern and an essential element for good planning and management (MartinezGarcia and Raya, 2008).

It has been empirically observed in the main issuing countries that the widespread trend is a drastic reduction of the length of time that tourists spend on holiday (Alegre and Pou, 2006), tendency that we find also in Italy. Related to this, in Figure 1, we show the variation in the average duration for holidays in Italy, broken down by regions of destination. The darkest colours correspond to regions in which the change is almost zero, the lighter identify negative variations, which are greater the brighter is the colour. From 2002 to 2008, we can notice that, only in three regions, the average duration has not changed, whereas in all the others, there has been a decrease, supporting the general trend. Also, Table 1 reports that in the last decade, there has been an increase in the number of holidays labelled short, i.e. up to three nights and, at same time, a decreasing trend in the general average duration, and this could be explained by different economic and sociodemographic factors. 


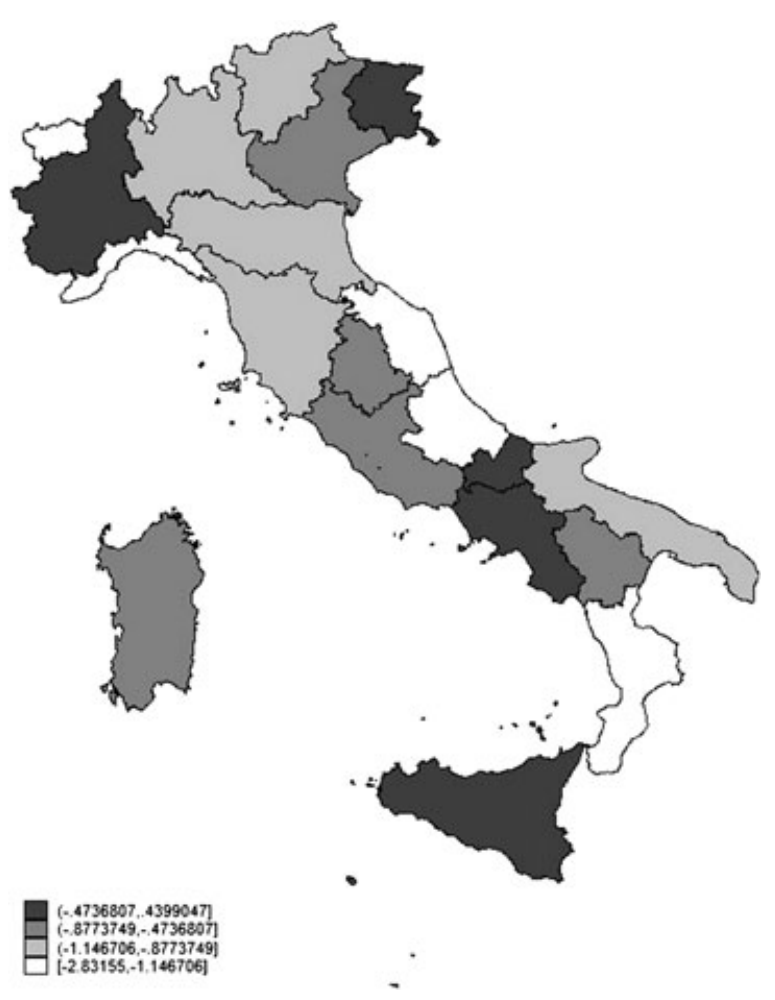

Figure 1. Average length of stay variation for the period 2002-2008.

One possible explanation of these features could be the change in preferences of tourists, who choose several short holidays rather than just one longer. At our knowledge, there are few studies that try to pursue this line of research, highlighting short- and long-holiday makers' preferences; one example can be found in the analysis proposed by Okamura and
Fukushige (2010), which investigates the differences in travel objectives of the two types of travellers at a given destination. Using a different perspective, based on holidays, and distinguishing between short and long stays, Alegre et al. (2010), instead, describe the characteristics of those tourists that are more likely to choose short rather than long holidays by defining a membership function.

The cited papers highlight one of the main distinctive feature of holiday duration: its empirical distribution function is not normal. We show clearly the multimodality of the length of stay in Figure 2, in Italy, stressing the increased frequency of short holidays in the period analysed.

In this paper, we account for this multimodality of duration, discriminating therefore between short and long stays as in Alegre et al. (2010), using a different empirical strategy, the count quantile regression (CQRM), which has been never used in this context before as long as we know. This statistical method allows us to estimate properly the measures of the demand reactivity helpful for the design of appropriate tourism strategies based on those economic determinants. Using the CQRM model, we can compute own price and income semi-elasticities for short and long stays, contributing to the literature on length-of-stay analysis, by giving a more detailed and accurate measure of the effect on the length of stay due to prices and income.

Not only preferences but also prices and income played an important role in determining the decreasing trend in holidays' duration: the recent financial crisis is strictly linked with a

Table 1. Dynamic of leisure and business stays, 2002-2008

\begin{tabular}{|c|c|c|c|c|c|c|c|c|c|c|}
\hline & \multicolumn{6}{|c|}{ Leisure } & \multicolumn{2}{|c|}{ Business } & \multicolumn{2}{|c|}{ Total } \\
\hline & \multicolumn{2}{|c|}{$1-3$ nights } & \multicolumn{2}{|c|}{4 nights or more } & \multicolumn{2}{|c|}{ Total } & \multirow[b]{2}{*}{$N^{\circ}$} & \multirow[b]{2}{*}{$\%$} & \multirow[b]{2}{*}{$N^{\circ}$} & \multirow[b]{2}{*}{$\%$} \\
\hline & $N^{\circ}$ & $\%$ & $N^{\circ}$ & $\%$ & $N^{\circ}$ & $\%$ & & & & \\
\hline 2002 & 35.333 & 37.4 & 45.134 & 47.8 & 80.467 & 85.2 & 14.028 & 14.8 & 94.495 & 100 \\
\hline 2003 & 35.670 & 38.0 & 43.720 & 46.5 & 79.391 & 84.5 & 14.614 & 15.5 & 94.004 & 100 \\
\hline 2004 & 38.069 & 38.8 & 45.068 & 45.9 & 83.137 & 84.7 & 14.984 & 15.3 & 98.120 & 100 \\
\hline 2005 & 43.039 & 40.2 & 49.081 & 45.8 & 92.120 & 86.0 & 14.974 & 14.0 & 107.094 & 100 \\
\hline 2006 & 43.662 & 40.5 & 50.228 & 46.5 & 93.890 & 87.0 & 14.006 & 13.0 & 107.895 & 100 \\
\hline 2007 & 47.911 & 42.6 & 49.262 & 43.9 & 97.173 & 86.5 & 15.196 & 13.5 & 112.369 & 100 \\
\hline 2008 & 55.919 & 45.5 & 50.891 & 41.4 & 106.810 & 86.9 & 16.128 & 13.1 & 122.938 & 100 \\
\hline
\end{tabular}




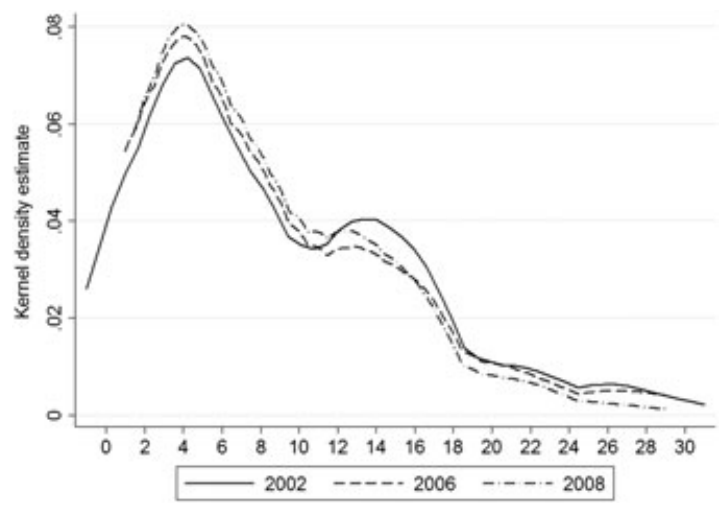

Figure 2. Average length of stay variation for the period 2002-2008.

severe household disposable income reduction, and also, prices have continued to grow, making more difficult for many Italian households to manage their finances. Our study aims especially to analyse which and in what extent also income and price have contributed to reduce the length of stay in Italy during the period from 2002 to 2008. Our estimates of the demand characteristics could support the forecasting of tourism demand, essential in assisting the managerial decision making, in the short term for scheduling, staffing and planning and in the longer term, to invest in infrastructures that also usually require public finances. Elasticities are particularly useful in providing an idea of how the tourism demand reacts when the determinants vary to assess the direction and the magnitude in which tourists would respond to changes in price or income (Huertas, 2006). Studying the determinants of tourism demand in terms of duration also can be useful in aggregate terms, at the industry level, especially for those countries, like Italy, that are, in large part, dependent on this sector. In fact, even if tourism continues to play a role in generating profits and employment opportunities, it faces the problem of maintaining a sustainable competitive advantage in an even more dynamic and globalized context, and gathering new and up-to-date information could help in exploiting the new trends (Huertas, 2006).

The remainder of this paper is structured as follows: in the second section, we briefly review the literature, highlighting the main problems in analysing holiday duration; then, in the third

Copyright (c) 2012 John Wiley \& Sons, Ltd. section, we present the econometric model used to estimate semi-elasticities. In the forth, we describe the datasets used, and finally, the fifth and sixth sections present the results and conclusions of our analysis.

\section{LITERATURE REVIEW}

The literature about tourism demand has analysed mainly traditional tourism measures, e.g. arrivals and/or departures and expenditure and/or receipts, but even if it is a relevant aspect in the decision-making process of tourists, very few studies focused on the length of stay. The very first approach to tourism demand analysis was based, to a great extent, on aggregate time series data, and only later, consumer models became more popular; in fact, using micro-data has the advantage to explore the direct link between the outcome that we care about and the policy variable (Deaton, 1998).

At our knowledge, the first analysis about the length of stay were those proposed by Mak et al. (1977) and Mak and Nishimura (1979), using data from a survey about US visitors to Hawaii. Later, Bell and Leeworthy (1990) tried to model the annual consumer demand for Florida beach days with a travel cost method; then, Fleischer and Pizam (2002) analysed the length of stay of older tourists in Israel using a Tobit model for censored data.

Recently, holiday duration has been studied by Alegre and Pou (2006), using a discrete choice logit model, Gokovali et al. (2007), MartinezGarcia and Raya (2008) and Pestana Barros and Pinto Machado (2010) who used survival analysis to model holiday duration and Alegre et al. (2010) who exploited a latent class truncated Poisson regression to account for groups or segments of demand.

Among the strategies used are the survival analysis and the logit approach model probabilities; the former focuses on the conditional probability of a tourist staying tdays, given that he stayed $t-1$ days (Kiefer, 1988), whereas the latter instead describes probabilities related to binary dependent variables, after having properly transformed the duration into a dichotomous variable. Among the two empirical strategies, survival analysis is preferred when covariates are time varying (Gokovali et al., 2007); however,

Int. J. Tourism Res. 14, 515-530 (2012)

DOI: $10.1002 /$ jtr 
in practice, the binary dependent variable model often is used because explanatories do not change so often in the course of the spell. The choice of the logit approach also is more appealing because setting an appropriate cutoff allows analysing particular types of holiday, e.g. short versus longer stays or holidays in weekly blocks.

Alegre et al. (2010) proposed a new empirical strategy to account for the existence of different tourist segments; in fact, they assume that there are two groups of tourists, those who prefer short stays and those who choose long stays. By taking into account group membership, they adopt a non-parametric approach to the length of stay without the possibility of policy considerations on parameters.

None of the studies mentioned above provide income and price elasticities, even if potentially useful for policy purposes; this information has been more explored using aggregate data or other outcome variables. A comprehensive review of the empirical literature on tourism demand is provided by Crouch (1994a, 1994b, 1995), Witt and Witt (1995), Lim (1997, 1999) and Li et al. (2005). According to Crouch (1992), the majority of studies measured elasticity looking at international tourist arrivals, some at expenditure and/or receipts, and just a minority used the length of stay as dependent variable; however, none provides elasticity estimates for different quintiles of the outcome. Although in general, tourism demand is considered positively related to income and negatively with touristic prices, we do not know if the magnitude of the relation is constant across the duration distribution or if the effect of income, for instance, is greater the longer is the holiday, but using quantile regression, we can address this question.

\section{THE MODEL}

\section{The theoretical framework}

We derive the determinants of the length of stay through the standard consumer maximization problem, where the utility function includes a vector of consumer goods that do not contain the tourist services, $q$; the vector of holiday characteristics, $z$; and the length of stay, $t$.

$$
\begin{gathered}
\underset{q, z, t}{\operatorname{Max} U}(q, z, t, \eta, \varepsilon) \\
p^{\prime} q+p_{t} t \leq Y \\
t \leq T \\
q, z, t, p, p_{t} \geq 0
\end{gathered}
$$

Adopting the discrete choice model perspective (McFadden, 1981), the utility function also includes a vector of taste shifters, $\eta$, and a random term for non-observable characteristics of the trip, $\varepsilon$. The consumer will maximize the utility, given income and time constraints, where $p$ is the vector of prices of $q$ and $p_{t}$ is the price of the holiday.

Following Pollak $(1969,1971)$, the conditional demand function for the length of stay at destination $j$ can be expressed by the following:

$$
t_{j}=f\left(p, p_{t}, z_{j}, Y, T, \eta, \varepsilon\right) .
$$

The length of holiday can be estimated using Equation (5) as conditional demand function, taking pre-assigned values for the choice of destination and the set of holiday characteristics, with the result that a certain choice partly determines the holiday length (Alegre and Pou, 2006).

\section{The econometric framework}

As already noticed in the literature, when the length of stay is used as dependent variable, the standard ordinary least squares (OLS) regression of spell time is not appropriate, not only because there is the possibility that for short durations, the linear regression model predicts negative values (Kiefer, 1988) but also, more importantly, because the error term distribution of the OLS regression is found to be not normally distributed due to the multimodality of its empirical distribution (Alegre and Pou, 2006). To account for this characteristic of holiday duration, we propose an alternative empirical strategy, the CQRM, that has never been used in this context. Differently from the OLS model, which estimates parameters at the mean value of the dependent variable, this methodology allows

Int. J. Tourism Res. 14, 515-530 (2012)

DOI: $10.1002 /$ jtr 
estimations for any quantile of the duration distribution and is capable of estimating different effects of prices, income, socio-demographic, tastes, trip and destination characteristics on the length of stay for different types of holidays, e.g. short and long stays by focusing on the effects of this variables at specific quantiles. The CQRM model is a variation of the usual quantile regression approach (Koenker and Basset, 1978) that accounts for the discrete nature of the dependent variable and was first introduced by Machado and Santos Silva (2005). The authors show that, if $Y$ is a discrete random variable and $X$ a vector of $k$ random variables (covariates), then the $100 \alpha$-th quantile of $Y$ when $X=x$ cannot be expressed as a continuous function of the parameters of interest, and sufficient conditions for asymptotically valid inference are not satisfied. A solution to the problem is to artificially impose smoothness to the data deriving a new conditional continuous quantile function. This procedure has been implemented using the so-called jittering sampling (Stevens, 1950) that we shortly describe in the following. Let $U$ be a random variable with continuous distribution function with support on $[0,1)$, called smoothing noise, which is independent from $Y$ and $X$. The count variate $Y$ can be transformed into a continuous variable $Z$ adding the smoothing noise $U:(Z=Y+U)$. It can be shown that, after the transformation, the artificial variable distribution is equivalent to that of the original variable, and their quantiles present a one-to-one relation. Then, the jittered sample $\left(y_{i}+u_{i}+x_{i}\right)$, with $i=1,2, \ldots, n$ is obtained drawing $u_{i}$ from the smoothing noise $\mathrm{e}^{1}$ variable $\mathrm{U}$ and will depend, as the estimates of the quantiles, on the specific realization $u_{i}$. To avoid dependence on specific realizations of $U$, Machado and Santos Silva (2005) proposed the average-jittering estimator, a new version of the traditional CQRM based on $m$ Monte Carlo replications. The authors show that this estimator has the relevant property to improve efficiency even when a small number $(m=10)$ of replications is adopted. The distribution function of the artificial variable $Z$ is continuous but does not have continuous

\footnotetext{
${ }^{1}$ The smoothing noise is usually uniformly distributed in the interval $[0,1)$ because important algebric and computational simplifications are possible.
}

derivatives for integer value, so a monotone transformation $T(Z, \alpha)$ must be applied to $Z$ to satisfy standard assumptions of the linear quantile regression. Following Machado and Santos Silva (2005), we consider the following transformation for $Z$ :

$$
T(Z, \alpha)=\left\{\begin{array}{lll}
\log (Z-\alpha) & \text { for } & Z>\alpha \\
\log (\theta) & \text { for } & Z \leq \alpha
\end{array}\right.
$$

where $\theta$ is a small positive number. Finally, a traditional quantile regression can be estimated, and the quantiles of the count variable are retrieved from the artificial distribution using the following expression:

$$
Q_{y}(\alpha / X)=\left(Q_{z}(\alpha / X)-1\right)
$$

Estimates of $Y$ quantiles are consistent, and any traditional inference based on $t, \mathrm{LR}$ and Wald statistics are valid (Machado and Santos Silva, 2005).

When quantile regressions are used, the interpretation of the coefficients in terms of marginal impact on the dependent variable is not so straightforward due to non-linearity. To fully understand the impacts of the covariates, it is possible to compute partial effects for specific individuals, denoted as $\tilde{x}$, so that the effect of a dummy variable, $d_{j}$, is

$$
\begin{aligned}
& Q_{z}\left(\alpha / \tilde{x}, d_{j}=1\right)-Q_{z}\left(\alpha / \tilde{x}, d_{j}=0\right) \\
& \quad=\left[\exp \left(\gamma_{j}(\alpha)\right)-1\right]\left[Q_{z}(\alpha / \tilde{x})-\alpha\right]
\end{aligned}
$$

where $\gamma_{j}(\alpha)$ is the coefficient estimated through the quantile regression. For a continuous variable instead, $x_{j}$, the effect is computed as follows

$$
\gamma_{j}(\alpha)\left[Q_{z}(\alpha / \tilde{x})-\alpha\right]
$$

The semi-elasticities are evaluated at the median value of the continuous variables and by setting the dummy variables to zero. Estimation was performed with the qcount package of STATA (Miranda, 2006) after some slight adjustments to properly interpret the results with respect to a reference category.

Int. J. Tourism Res. 14, 515-530 (2012) DOI: $10.1002 /$ jtr 


\section{DATA}

The data used in the analysis were drawn from the yearly Multipurpose survey on business and leisure travels of ISTAT. The original sample size in the survey is about 14000 Italian households and provides information about the trips done in a particular quarter of the year and the socio-demographic characteristics of each household member, i.e. education, occupation, age and marital status. Information about the trip is the period in terms of quarter, duration of the stay, destination, location, accommodation type and motivation. In this paper, we do not consider holidays abroad because a comparable touristic price was not available. Although some researchers argued that tourists respond to exchange rate movements much more than to changes in relative inflation rates, when they make decisions on the travel destination (Artus, 1972), Martin and Witt (1987) argue that the exchange rate alone is not an acceptable proxy for tourism costs.

What is missing in the original ISTAT dataset is information about individual/household income and prices. Those variables were fundamental for the analysis; therefore, we used other sources, The Bank of Italy's dataset about Italian households' income and ISTAT price indexes data. The Bank of Italy provides detailed information about Italian households' income and socio-demographic characteristics on the basis of a sample composed by about 8000 households for the years considered. To exploit that information, we matched the Bank of Italy's observations with ISTAT data, using a statistical technique, the propensity score matching - PSM (Rosenbaum and Rubin, 1983). For a correct matching, two conditions have to be met: one concerns the samples, and the other involves the available information in the two databases. It is required that the two samples are drawn randomly from the same population and, second, that there is a set of common variables in the two datasets; these two requirements in our case are satisfied, in particular the set of common variables are the socio-demographic and economic characteristics of the household. ${ }^{2}$ To show the validity of the procedure, in Table 2,

${ }^{2}$ For a detailed list of the variables used to compare the two datasets, see appendix A. we compared means and quartiles of the two distributions. ${ }^{3}$ The table shows that the two distributions are quite similar for each year considered; it seems that after using the propensity score matching, income is overestimated in the ISTAT sample, but the differences are negligible. For more detailed information about the matching technique, see Rosenbaum and Rubin (1983). Prices variables, i.e. the regional price for touristic services ${ }^{4}$ and the general price index, were obtained by ISTAT. We also used the general price index to construct a real equivalent household income.

\section{EMPIRICAL RESULTS}

In this section, we report the results obtained from the count quantile regression model described above. The dependent variable, as already discussed, is the length of stay of the holiday, whereas a list of the covariates used is reported in Table 3 . To estimate semi-elasticities consistent with the theoretical model presented in section 3, we used a wide number of control variables related to holiday characteristics (e.g. type of accommodation, mean of transportation, price of touristic services), tourists characteristics (share of participants in given age bands, level of education, household income, marital status and employment status), type of destination (seaside, mountain, lake, countryside, agrotourism, cultural cities, touristic or study/sport holidays) and year and quarter dummies to control for seasonality. To catch shifts in tourists' preferences from a given destination to another, we included a series of interaction terms between destination types and years. The Poisson estimates and those for each quantile are summarized in Table 4. We report also the Poisson estimates to provide a comparison with CQRM and show how far would be the policy measure for each quantile.

All the control variables have the expected sign; among accommodation types, we find that, generally, house rented, multi-properties,

\footnotetext{
${ }^{3}$ We also made a more detailed comparison, controlling that the income distribution conditional to the variables used to perform propensity score matching were similar in the two datasets.

${ }^{4}$ As touristic services we consider the price for accommodation and for restaurants in the region of destination.
}

Int. J. Tourism Res. 14, 515-530 (2012) 
Table 2. Means and quartiles of the two income distributions, 2006

\begin{tabular}{lcccccccc}
\hline & \multicolumn{2}{c}{2002} & & \multicolumn{2}{c}{2006} & & \multicolumn{2}{c}{2008} \\
\cline { 2 - 3 } \cline { 8 - 9 } \cline { 8 - 9 } & ISTAT & Bank of Italy & & ISTAT & Bank of Italy & & ISTAT & Bank of Italy \\
\hline 25th percentile & 15.850 & 14.200 & & 20.200 & 17.000 & & 18.600 & 17.860 \\
50th percentile & 23.600 & 22.500 & & 28.109 & 25.600 & & 29.526 & 26.600 \\
75th percentile & 36.500 & 33.927 & & 41.600 & 38.400 & & 41.500 & 40.000 \\
Mean & 27.853 & 25.489 & & 31.828 & 29.193 & & 32.138 & 30.904 \\
Number of observations & 14.024 & 7.811 & & 14.004 & 7.572 & & 14.008 & 7.897 \\
\hline
\end{tabular}

camping and houses for free are preferred for longer stays, whereas agrotourism and bed and breakfast do not appear to be significant across quantiles. The preferred mean of transportation for long holidays are plane, train, ship and rented car, whereas bus and camper are not relevant across quantiles of duration. Looking at tourist characteristics, it appears that people aged 65 or older - i.e. retired - are those who make longer holidays compared with the other age groups; moreover, educated people are more likely to stay for shorter periods than people with low education, and this relation becomes stronger for higher quantiles of the length of stay distribution. Married people spend shorter holidays than single and widowed, but there are no differences with divorced and separated. The length of stay increases with the number of participants presenting a stronger effect until the 75th percentile, and then, it decreases. The seaside, which, in our model was used as the reference category, ${ }^{5}$ is the preferred destination for longer holidays; in fact, all the coefficients associated with other destinations are always negative or non-significant, meaning that the average stay for all destinations is lower than that of seaside locations. The third quarter is the one which records the highest durations, with increasing effect across quantiles. The coefficients associated with year dummies are negative and decreasing in their effects across quantiles, consistent with the average length of stay decrease documented in the introduction. If we look at the interaction variables, we can see that most of them are not signifsicant, i.e. tourists did not change their

\footnotetext{
${ }^{5}$ We checked that by changing the reference category, we obtained a significant coefficient associated with seaside.
}

Copyright @ 2012 John Wiley \& Sons, Ltd. preferences across years for those destinations, but interestingly, cultural holidays report a positive coefficient for both 2006 and 2008, meaning that the affluence of visitors for these locations has increased in the years considered. Moreover, the effect increases across quantiles and is particularly significant at the 25th, 50th, 75th and 90th quantiles, which corresponds to holidays of 1, 3, 7 and 14 days respectively, in the length of stay distribution of our sample. This result seems quite relevant for policymakers to better exploit all territorial resources.

The income variable also is significant and with positive sign, according to economic theory, in fact, length of stay should be higher for richer households. As we can see from Table 4 , the estimated coefficient for this variable increases until the 75th quantile and then slightly decreases. The coefficient of price is negative and significant for all the considered quantiles with decreasing impact for higher ones. Table 5 reports the estimated marginal effects and semi-elasticities for the quantiles of the length of stay distribution. It is possible to notice that both price and income marginal effects have stronger -negative or positive respectively - effects on longer holidays, meaning that an income decrease or a price increase would imply a more relevant reduction in terms of days on longer holidays rather than on short. For example, if we consider the average household in our sample, a drop in income by $1 \%$ would imply a reduction in the length of stay of 0.02 days for each quantile. The same exercise can be repeated with prices of accommodations and restaurants to evaluate the impact of a $1 \%$ price increase on the length of stay. In this case, we can see that there is an increasing effect across quantiles passing from -1.26 at the 10th quantile to -0.85 at the 75 th. It is interesting 
Table 3. Data definitions

\begin{tabular}{|c|c|}
\hline Variable & Description \\
\hline Q1 & First quarter \\
\hline$\widehat{Q} 2$ & Second quarter \\
\hline$\widehat{Q} 3$ & Third quarter \\
\hline$\widehat{Q} 4$ & Fourth quarter \\
\hline $\log y$ & Logarithm of real annual household income \\
\hline $\log p$ & Logarithm of price of touristic services (includes accommodations and restaurants) \\
\hline $\mathrm{d} 02$ & Dummy for the year 2002 \\
\hline d06 & Dummy for the year 2006 \\
\hline d08 & Dummy for the year 2008 \\
\hline Age class1 & Percentage of participants aged between 18 and 29 years old \\
\hline Age class2 & Percentage of participants aged between 30 and 49 years old \\
\hline Age class3 & Percentage of participants aged between 50 and 64 years old \\
\hline Age class 4 & Percentage of participants aged more than 65 years old \\
\hline Npart & Number of participants \\
\hline Male & Percentage of male participants \\
\hline Female & Percentage of female participants \\
\hline Primed & Percentage of participants with primary or no education. \\
\hline Seced & Percentage of participants with secondary education. \\
\hline Highed & Percentage of participants with high education, degree or more. \\
\hline Employed & Percentage of employed participants \\
\hline Unempl & Percentage of unemployed participants \\
\hline Married & Percentage of married participants \\
\hline Widowed & Percentage of widowed participants \\
\hline Divorced & Percentage of divorced participants \\
\hline Separated & Percentage of separated participants \\
\hline Single & Percentage of single participants \\
\hline North West dest & North-West Italy destination \\
\hline North East dest & North-East Italy destination \\
\hline Central dest & Central Italy destination \\
\hline South dest & Southern Italy destination \\
\hline Islands dest & Italian islands destination \\
\hline Seaside & Seaside destination \\
\hline Mountain & Mountain destination \\
\hline Lake & Lake destination \\
\hline Countryside & Countryside destination \\
\hline Rural & Rural destination \\
\hline Cultural & Cultural destination \\
\hline Tourtrav & Touristic travel destination \\
\hline Study/Sport & Study/Sport Holiday destination \\
\hline Car & Mean of transportation: car \\
\hline Plane & Mean of transportation: airplane \\
\hline Train & Mean of transportation: train \\
\hline Ship & Mean of transportation: ship \\
\hline Car rented & Mean of transportation: car rented \\
\hline Bus & Mean of transportation: bus \\
\hline Tour Bus & Mean of transportation: touristic bus \\
\hline Camper & Mean of transportation: camper \\
\hline Hotel & Accommodation: hotel \\
\hline Village & Accommodation: village \\
\hline Camping & Accommodation: camping \\
\hline House rented & Accommodation: house rented \\
\hline
\end{tabular}


Table 3. (Continued)

\begin{tabular}{ll}
\hline Variable & \\
\hline Multi-property & Accommodation: multi-property \\
Free house & Accommodation: free house \\
Agrotourism & Accommodation: agrotourism \\
B\&B & Accommodation: bed and breakfast \\
Other & Accommodation: other \\
Cons & Constant \\
\hline
\end{tabular}

Table 4. Length of stay Poisson and count quantile regression estimates

\begin{tabular}{|c|c|c|c|c|c|c|}
\hline Variables & Poisson & Q 0.10 & Q 0.25 & Q 0.50 & Q 0.75 & Q 0.90 \\
\hline Q1 & $-0.70^{* * *}$ & $-0.32^{* * *}$ & $-0.50^{* * *}$ & $-0.74^{* * *}$ & $-0.76^{* * *}$ & $-0.72^{* * *}$ \\
\hline Q2 & $-0.60^{* * *}$ & $-0.32^{* * *}$ & $-0.49^{* * *}$ & $-0.68^{* * *}$ & $-0.68^{* * *}$ & $-0.58^{* * *}$ \\
\hline$\widetilde{\mathrm{Q}} 4$ & $-0.85^{* * *}$ & $-0.37^{* * *}$ & $-0.53^{* * *}$ & $-0.78^{* * *}$ & $-0.92^{* * *}$ & $-0.94^{* * *}$ \\
\hline d06 & $-0.10^{* * *}$ & -0.01 & -0.02 & $-0.08^{* *}$ & $-0.09^{* *}$ & $-0.14^{* * *}$ \\
\hline $\mathrm{d} 08$ & $-0.21^{* * *}$ & -0.04 & $-0.11^{* * *}$ & $-0.23^{* * *}$ & $-0.24^{* * *}$ & $-0.26^{* * *}$ \\
\hline $\log y$ & $0.03^{* * *}$ & $0.02^{*}$ & $0.02^{*}$ & $0.03^{* * *}$ & $0.03^{* * *}$ & $0.02^{*}$ \\
\hline $\log p$ & $-1.17^{* * *}$ & $-1.36^{* * *}$ & $-1.21^{* * *}$ & $-1.12^{* * *}$ & $-0.95^{* * *}$ & -0.23 \\
\hline Age class1 & $-0.36^{* * *}$ & $-0.21^{* * *}$ & $-0.31^{* * *}$ & $-0.35^{* * *}$ & $-0.36^{* * *}$ & $-0.35^{* * *}$ \\
\hline Age class2 & $-0.42^{* * *}$ & $-0.21^{* * *}$ & $-0.36^{* * *}$ & $-0.38^{* * *}$ & $-0.40^{* * *}$ & $-0.39^{* * *}$ \\
\hline Age class3 & $-0.27^{* * *}$ & $-0.09 * *$ & $-0.22^{* * *}$ & $-0.23^{* * *}$ & $-0.22^{* * *}$ & $-0.22^{* * *}$ \\
\hline North West dest & $-0.13^{* * *}$ & $-0.11^{* * *}$ & $-0.18^{* * *}$ & $-0.19^{* * *}$ & $-0.16^{* * *}$ & $-0.11^{* * *}$ \\
\hline Central dest & $-0.04^{*}$ & 0.01 & -0.03 & $-0.05^{* *}$ & $-0.09 * * *$ & $-0.09^{* * *}$ \\
\hline South dest & 0.00 & -0.01 & 0.01 & -0.03 & -0.04 & -0.02 \\
\hline Islands dest & -0.00 & $-0.08^{*}$ & -0.06 & -0.04 & -0.03 & -0.03 \\
\hline Npart & $0.06^{* * *}$ & $0.05^{* * *}$ & $0.06^{* * *}$ & $0.07^{* * *}$ & $0.08^{* * *}$ & $0.05^{* * *}$ \\
\hline Male & $-0.06^{* * *}$ & $-0.12^{* * *}$ & $-0.08^{* * *}$ & $-0.07^{* * *}$ & $-0.07^{* * *}$ & -0.03 \\
\hline Seced & -0.01 & 0.00 & 0.02 & 0.00 & 0.01 & -0.02 \\
\hline Highed & $-0.07^{* *}$ & 0.01 & 0.02 & $-0.06^{*}$ & $-0.07^{*}$ & $-0.09^{* *}$ \\
\hline Unempl & 0.06 & -0.01 & 0.00 & -0.04 & 0.05 & 0.17 \\
\hline Single & $0.06^{* *}$ & $-0.11^{* * *}$ & -0.04 & -0.01 & 0.03 & $0.08^{* * * *}$ \\
\hline Widowed & $0.24^{* * * *}$ & 0.06 & $0.27^{* * *}$ & $0.26^{* * *}$ & $0.27^{* * *}$ & $0.25^{* * *}$ \\
\hline Divorced & 0.10 & -0.08 & $-0.13^{*}$ & -0.11 & 0.11 & $0.16^{* *}$ \\
\hline Separated & 0.02 & 0.11 & 0.09 & 0.02 & -0.05 & -0.01 \\
\hline Mountain & $-0.10^{* * *}$ & -0.08 & -0.05 & $-0.14^{* * *}$ & -0.03 & $-0.08^{*}$ \\
\hline Mountain*d06 & 0.02 & 0.10 & 0.07 & $0.14^{* *}$ & 0.01 & 0.00 \\
\hline Mountain*d08 & 0.02 & 0.01 & 0.09 & $0.17^{* * * *}$ & 0.01 & 0.08 \\
\hline Lake & $-0.37^{* * *}$ & $-0.19^{*}$ & $-0.20^{*}$ & $-0.38^{* * *}$ & $-0.48^{* * *}$ & $-0.47^{* * *}$ \\
\hline Lake*d06 & 0.15 & 0.10 & 0.07 & $0.31^{* *}$ & 0.27 & 0.07 \\
\hline Lake*d08 & -0.03 & -0.03 & -0.04 & 0.01 & 0.09 & 0.13 \\
\hline Countryside & $-0.47^{* * *}$ & $-0.24^{* * *}$ & $-0.34^{* * *}$ & $-0.57^{* * *}$ & $-0.58^{* * *}$ & $-0.50^{* * *}$ \\
\hline Countryside*d06 & 0.05 & 0.11 & 0.07 & 0.17 & 0.18 & 0.00 \\
\hline Countryside ${ }^{*} \mathrm{~d} 08$ & $0.43^{* * *}$ & 0.03 & 0.00 & 0.21 & $0.47^{* *}$ & $0.45^{* * *}$ \\
\hline Rural & $-0.21^{*}$ & -0.11 & -0.02 & -0.18 & -0.19 & $-0.20^{* *}$ \\
\hline Rural*d06 & -0.18 & 0.12 & -0.15 & -0.06 & -0.19 & $-0.38^{* * *}$ \\
\hline Rural $^{*}$ d08 & 0.06 & 0.11 & -0.06 & 0.02 & -0.17 & -0.24 \\
\hline Cultural & $-0.47^{* * *}$ & $-0.15^{* *}$ & $-0.29 * * *$ & $-0.39^{* * *}$ & $-0.47^{* * *}$ & $-0.55^{* * *}$ \\
\hline Cultural*d06 & 0.10 & 0.09 & $0.16^{* *}$ & $0.13^{* *}$ & $0.13^{* *}$ & $0.16^{*}$ \\
\hline Cultural*d08 $^{*}$ & $0.20^{* * *}$ & -0.04 & $0.16^{* *}$ & $0.19^{* * *}$ & $0.23^{* * *}$ & $0.22^{* *}$ \\
\hline Tourtrav & $-0.35^{* * *}$ & $-0.17^{* * *}$ & $-0.21^{* * *}$ & $-0.28^{* * *}$ & $-0.32^{* * *}$ & $-0.34^{* * *}$ \\
\hline
\end{tabular}


Table 4. (Continued)

\begin{tabular}{lcccccc}
\hline Variables & Poisson & Q 0.10 & Q 0.25 & Q 0.50 & Q 0.75 & Q 0.90 \\
\hline Tourtrav*d06 & 0.06 & -0.00 & -0.03 & -0.06 & -0.02 & 0.10 \\
Tourtrav*d08 & $0.16^{* *}$ & 0.07 & $0.19^{* * *}$ & $0.15^{* *}$ & 0.09 & 0.13 \\
Study/Sport & $-0.42^{* * *}$ & $-0.37^{* * *}$ & $-0.52^{* * *}$ & $-0.66^{* * *}$ & $-0.62^{* * *}$ & $-0.59^{* * *}$ \\
Study/Sportd06 & 0.01 & 0.04 & $0.15^{*}$ & $0.21^{* *}$ & 0.11 & 0.10 \\
Study/Sport*d08 & 0.11 & $0.24^{* * *}$ & $0.24^{* * *}$ & $0.29^{* * * *}$ & $0.24^{* *}$ & $0.31^{*}$ \\
Plane & $0.31^{* * *}$ & $0.42^{* * *}$ & $0.48^{* * *}$ & $0.40^{* * *}$ & $0.33^{* * *}$ & $0.23^{* * * *}$ \\
Train & $0.12^{* * *}$ & $0.07^{* *}$ & $0.15^{* * *}$ & $0.14^{* * *}$ & $0.12^{* * *}$ & $0.09^{* *}$ \\
Ship & $0.21^{* * *}$ & $0.37^{* * *}$ & $0.40^{* * *}$ & $0.34^{* * *}$ & $0.31^{* * *}$ & $0.19^{* * *}$ \\
Car rented & $0.38^{* * *}$ & 0.08 & $0.22^{*}$ & 0.32 & $0.30^{* * *}$ & 0.14 \\
Bus & -0.01 & 0.07 & 0.05 & -0.02 & 0.03 & 0.10 \\
Tour Bus & 0.03 & 0.06 & 0.04 & -0.00 & 0.04 & 0.01 \\
Camper & 0.08 & 0.09 & $0.16^{* * *}$ & 0.08 & 0.05 & $0.14^{* *}$ \\
Village & $0.18^{* * *}$ & $0.53^{* * *}$ & $0.48^{* * *}$ & $0.19^{* * *}$ & $0.15^{* * *}$ & $0.12^{* * *}$ \\
Camping & $0.19^{* * *}$ & 0.07 & 0.03 & $0.15^{* * * *}$ & $0.20^{* * *}$ & $0.22^{* * *}$ \\
House rented & $0.50^{* * *}$ & $0.54^{* * *}$ & $0.59^{* * *}$ & $0.58^{* * *}$ & $0.49^{* * *}$ & $0.42^{* * *}$ \\
Multi-property & $0.22^{* * *}$ & 0.04 & -0.04 & -0.01 & $0.16^{* * *}$ & $0.33^{* * *}$ \\
Free house & $0.17^{* * *}$ & 0.03 & -0.00 & $0.06^{* *}$ & $0.15^{* * *}$ & $0.22^{* * *}$ \\
Agrotourism & -0.00 & -0.00 & -0.08 & 0.00 & 0.11 & 0.09 \\
B\&B & 0.03 & 0.13 & $0.12^{*}$ & 0.06 & -0.04 & 0.04 \\
Other house & $-0.15^{* *}$ & $-0.17^{* *}$ & $-0.40^{* * *}$ & $-0.27^{* * *}$ & -0.20 & -0.07 \\
Constant & $7.44^{* * *}$ & $6.99^{* * *}$ & $6.82^{* * *}$ & $7.07^{* * * *}$ & $6.70^{* * *}$ & $3.80^{* *}$ \\
Observations & 11,094 & 11,094 & 11,094 & 11,094 & 11,094 & 11,094 \\
\hline
\end{tabular}

Significance level: ${ }^{* * *} p<0.01,{ }^{* *} p<0.05,{ }^{*} p<0.1$

to notice that the price is not effective at the 90th quantile; as already said, this quantile corresponds to holidays lasting 14 days on average, and from our results, it seems that regional price variability does not affect duration significantly. This result means that the choice of a long holiday is more affected by the household's income level and probably by the possibility of participants to stay for such a long period. The result also could be driven by the characteristics of the supply of long holidays, which usually are associated with a fixed accommodation rental period. This type of take-it-or-leave-it contracts does not allow the tourist to adjust the number of days in relation to price changes; therefore, income remains to be the only economic determinant.

It also is interesting to look at some other variables that may influence the length of stay decision. As already mentioned before, the education is significant only at the top of the length distribution with an increasing semielasticity, ranging from -0.05 to -0.08 . This could be explained by a higher preference toward cultural destinations than usually record shorter stays.

About age effects, we can see that all the categories record increasing negative marginal effects, but in terms of semi-elasticity, we do not find significant differences across the distribution. In relation to marital status, we can notice that widowed people have a significant and increasing marginal effect above the 25th quantile, and also, the semi-elasticity follows the same pattern. Finally, we can notice that the number of participants has an increasing marginal effect along the distribution; this trend can be identified also in terms of semielasticity. This can be read as the fact that shorter stays are less reactive to the number of participants than longer holidays at least up to the 90th quantile.

\section{CONCLUSIONS}

In this paper, we have presented a methodology based on count quantile regression that also can be used to evaluate price and income

Int. J. Tourism Res. 14, 515-530 (2012) 


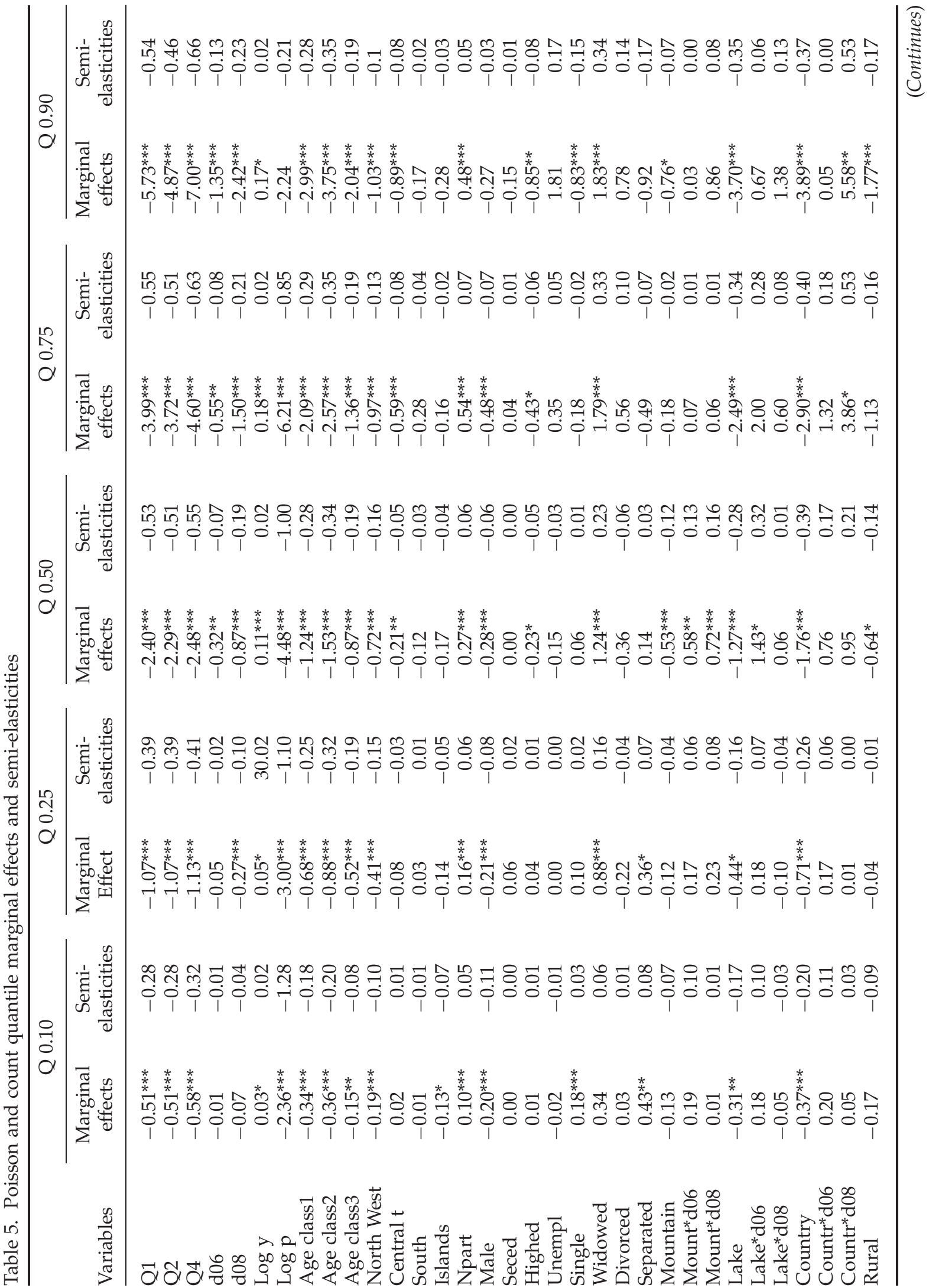




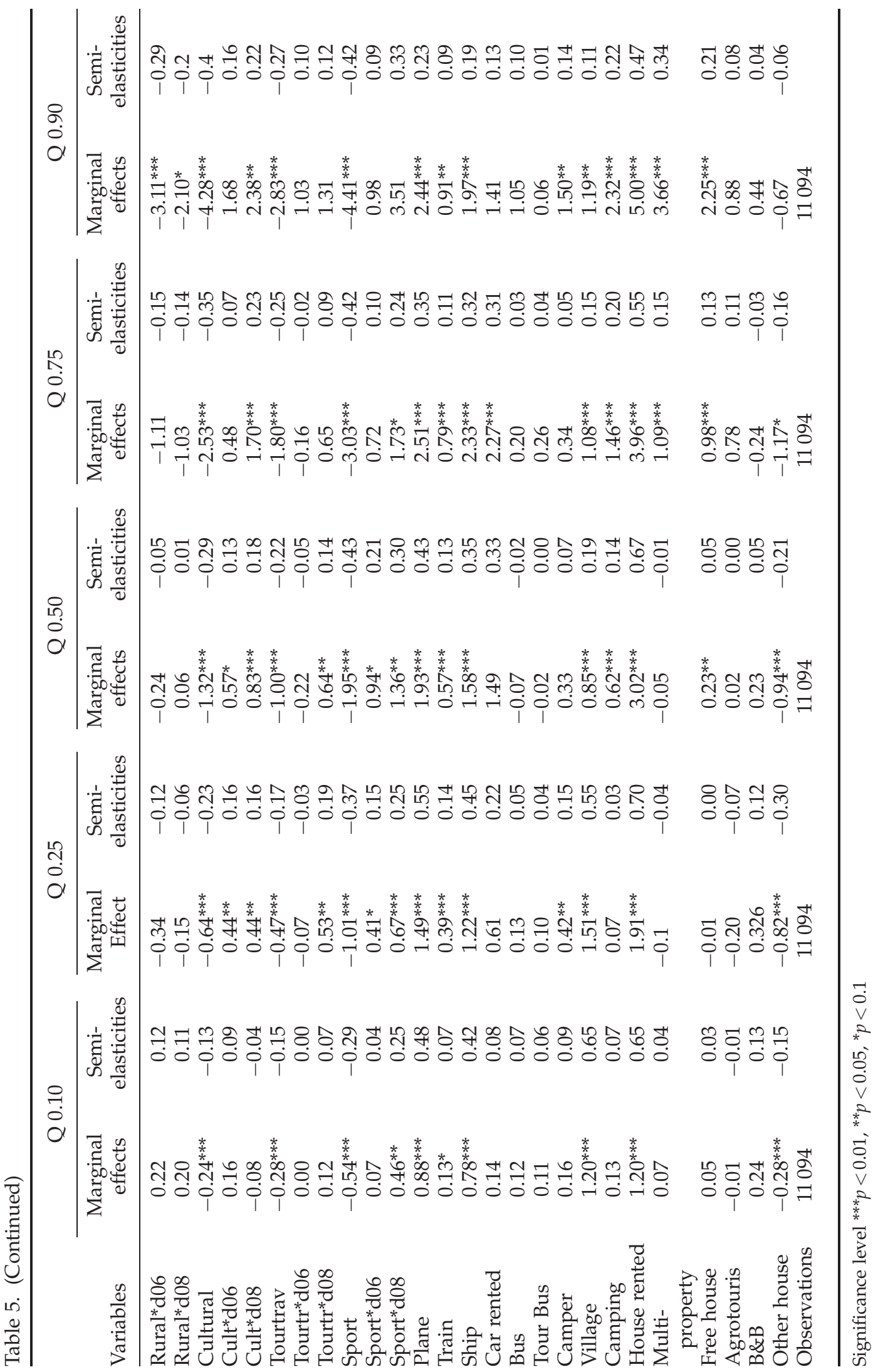


semi-elasticities of the length of stay. By doing this, we consider properly the coexistence of short and long holidays, which implies a nonnormal error term distribution that could lead to incorrect estimates if we rely only on the OLS model. Differentiating by quantiles and controlling by a wide number of variables allow us to estimate different effects for price of touristic services, real income and other controls. Since income was not available in our original dataset, we imputed this information using the SHIW database from Bank of Italy. Our main conclusion is that the length of stay decrease in Italy in the period 2002-2008 can be seen as the result of a variety of causes, of course, an income effect, which is significant for almost every quantile analysed and has an evident increasing marginal effect for higher quantiles (e.g. longer holidays). Second, we also find evidence of a price effect, which is negative and significant across quantiles except for the last one. Our approach allows the same analysis also for other important policy variable related to socio-demographic or stays' characteristics.

It would be interesting to use the same approach to other countries, e. g. the Mediterranean countries, to understand if some Italian results can be found in similar situations, an open question that needs further research.

APPENDIX A: Join table for PSM on multipurpose survey on business and leisure travels (ISTAT) and SHIW (BKI)

\begin{tabular}{lll}
\hline ISTAT & Bank of Italy & ISTAT and Bank of Italy \\
\hline
\end{tabular}

Multipurpose survey on

business and leisure

travels

Family ID

Individual ID

Survey on wealth and income of Italian

households

Family ID

Individual ID
Family ID

Individual ID

Territorial Partition

\begin{tabular}{lll}
\hline $1=$ North west Italy & $1=$ North west Italy & $1=$ North west Italy \\
$2=$ North east Italy & $2=$ North east Italy & $2=$ North east Italy \\
$3=$ Central Italy & $3=$ Central Italy & $3=$ Central Italy \\
$4=$ South Italy & $4=$ South Italy & $4=$ South Italy \\
$5=$ Italian islands & $5=$ Italian islands & $5=$ Italian islands
\end{tabular}

Household structure

\begin{tabular}{|c|c|c|}
\hline Number of components & Number of components & Number of components \\
\hline Family relationship & Family relationship & Family relationship \\
\hline $\begin{array}{c}1=\text { Reference person } \\
\text { (respondent) }\end{array}$ & $1=$ Reference person (respondent) & $\begin{array}{l}1=\text { Reference person } \\
\text { (respondent) }\end{array}$ \\
\hline $2=$ Spouse & $2=$ Spouse or cohabitant & $2=$ Spouse or cohabitan \\
\hline $3=$ Cohabiting & $3=$ Child & $3=$ Child \\
\hline $4=$ Parent & $4=$ Other & $4=$ Other \\
\hline $5=$ Father $/$ mother in law & & \\
\hline $\begin{array}{l}6=\text { Child from the } \\
\text { current marriage }\end{array}$ & & \\
\hline $7=$ Child from previous & & \\
\hline marriage & & \\
\hline $8=$ Son $/$ daughter in law & & \\
\hline cohabitant & & \\
\hline
\end{tabular}


(Continued)

\begin{tabular}{|c|c|c|}
\hline ISTAT & Bank of Italy & ISTAT and Bank of Italy \\
\hline $\begin{array}{l}\text { Multipurpose survey on } \\
\text { business and leisure } \\
\text { travels }\end{array}$ & $\begin{array}{l}\text { Survey on wealth and income of Italian } \\
\text { households }\end{array}$ & \\
\hline \multicolumn{3}{|l|}{$\begin{array}{l}10=\text { Grandson } / \\
\text { granddaughter }\end{array}$} \\
\hline \multicolumn{3}{|l|}{$11=$ Nephew } \\
\hline \multicolumn{3}{|l|}{$12=$ Brother $/$ sister } \\
\hline \multicolumn{3}{|l|}{$\begin{array}{c}13=\text { Brother } / \text { sister of } \\
\text { spouse } / \text { cohabitant }\end{array}$} \\
\hline \multicolumn{3}{|l|}{$\begin{array}{l}14=\text { Husband } / \text { wife of } \\
\text { brother/sister }\end{array}$} \\
\hline \multicolumn{3}{|l|}{$\begin{array}{l}15=\text { Cohabitant of } \\
\text { brother } / \text { sister }\end{array}$} \\
\hline \multicolumn{3}{|l|}{$\begin{array}{l}16=\text { Grandfather } / \\
\text { grandmother }\end{array}$} \\
\hline \multicolumn{3}{|l|}{$17=$ Cousin } \\
\hline \multicolumn{3}{|l|}{$18=$ Uncle $/$ aunt } \\
\hline \multicolumn{3}{|l|}{$19=$ Other relative } \\
\hline $20=$ Friend & & \\
\hline
\end{tabular}

\section{Gender}

\begin{tabular}{lll}
\hline $1=$ Male & $1=$ Male & $1=$ Male \\
$2=$ Female & $2=$ Female & $2=$ Female
\end{tabular}

Age

\begin{tabular}{lll}
\hline Age in years & Age in years & Age in years
\end{tabular}

Marital status

\begin{tabular}{|c|c|c|}
\hline $1=$ Single & $1=$ Married & $1=$ Married \\
\hline $\begin{array}{l}2=\text { Married or } \\
\text { cohabitating with } \\
\text { spouse }\end{array}$ & $2=$ Single & $2=$ Single \\
\hline $\begin{array}{l}3=\text { Separated } \\
4=\text { Legally separates }\end{array}$ & $\begin{array}{l}3=\text { Separated } / \text { divorced } \\
4=\text { Widowed }\end{array}$ & $\begin{array}{l}3=\text { Separated } / \text { divorced } \\
4=\text { Widowed }\end{array}$ \\
\hline
\end{tabular}

$5=$ Divorced

$6=$ Widowed

Education

\begin{tabular}{lll}
\hline $\begin{array}{l}1=\text { PhD or other post- } \\
\text { degree spec. }\end{array}$ & $1=$ No education & $1=$ No education \\
$2=$ Master degree & $2=$ Primary education & $2=$ Primary education \\
$\begin{array}{l}3=\text { Bachelor } \\
4=\text { Secondary education }\end{array}$ & $\begin{array}{l}3=\text { Secondary education } \\
4 / 5 \text { years }\end{array}$ & $\begin{array}{l}3=\text { Segree } \\
4=\text { Degree }\end{array}$ \\
$\begin{array}{l}5=\text { Secondary education } \\
\text { 2/3 years }\end{array}$ & $5=$ PhD or otherpost-degree spec. & $5=$ PhD or otherpost-degree spec. \\
$\begin{array}{l}\text { 6 }=\text { Primary education } \\
7=\text { No education }\end{array}$ & &
\end{tabular}


(Continued)

\begin{tabular}{lcc}
\hline ISTAT & Bank of Italy & ISTAT and Bank of Italy \\
\hline $\begin{array}{l}\text { Multipurpose survey on } \\
\text { business and leisure } \\
\text { travels }\end{array}$ & Survey on wealth and income of Italian \\
households & \\
\hline
\end{tabular}

Occupation

\begin{tabular}{|c|c|c|}
\hline $1=$ Employed & $1=$ Employed & $1=$ Employed \\
\hline $2=$ Looking for $a$ job & $2=$ Looking for the first job & $2=$ Looking for the first job \\
\hline $\begin{array}{l}3=\text { Looking for the first } \\
\text { job }\end{array}$ & $3=$ Housewife & $3=$ Housewife \\
\hline $4=$ Military service & $4=$ Retired & $4=$ Retired \\
\hline $5=$ Housewife & $5=$ Unemployed & $5=$ Unemployed \\
\hline $6=$ Student & $6=$ Student & $6=$ Student \\
\hline $\begin{array}{l}7=\text { Unfit for work } \\
8=\text { Retired }\end{array}$ & $7=$ Other & $7=$ Other \\
\hline
\end{tabular}

Occupational status

\begin{tabular}{lll}
\hline $1=$ Executive $/$ manager & $1=$ Worker & $1=$ Worker \\
$2=$ White collar & $2=$ Blue collar & $2=$ Blue collar \\
$3=$ Blue collar & $3=$ White collar & $3=$ White collar \\
$4=$ Worker & $4=$ Executive $/$ manager & $4=$ Executive $/$ manager \\
$5=$ Apprentice & $5=$ Freelancer & $5=$ Freelancer \\
$6=$ Entrepreneur & $6=$ Entrepreneur $/$ self-employed & $6=$ Entrepreneur $/$ self-employed \\
& worker & worker \\
$7=$ Freelancer & $7=$ Other & $7=$ Other
\end{tabular}

$8=$ Self-employed worker

Economic sector

\begin{tabular}{|c|c|c|}
\hline $\begin{array}{l}1=\text { Agriculture, hunting, } \\
\text { fishing }\end{array}$ & 1 = Agriculture & $\begin{array}{l}1 \text { = Agriculture, hunting, } \\
\text { fishing }\end{array}$ \\
\hline $\begin{array}{l}2=\text { Industry, mining, } \\
\text { manufacturing, energy }\end{array}$ & $2=$ Industry & $\begin{array}{l}2 \text { = Industry, mining, } \\
\text { manufacturing, energy }\end{array}$ \\
\hline $3=$ Construction & $3=$ Construction & $3=$ Construction \\
\hline $\begin{array}{l}4=\text { Wholesale, retail, } \\
\text { hotel and restaurants }\end{array}$ & $\begin{array}{l}4=\text { Wholesale, retail, hotel } \\
\text { and restaurants }\end{array}$ & $\begin{array}{l}4=\text { Wholesale, retail,hotel and } \\
\text { restaurants }\end{array}$ \\
\hline $\begin{array}{l}5=\text { Transports, stocking } \\
\text { and comunications }\end{array}$ & $\begin{array}{l}5=\text { Transports, stocking and } \\
\text { comunications }\end{array}$ & $\begin{array}{l}5=\text { Transports, stocking } \\
\text { and comunications }\end{array}$ \\
\hline $\begin{array}{l}6=\text { Intermediations } \\
\text { renting and other } \\
\text { professional services }\end{array}$ & $\begin{array}{l}6=\text { Intermediations, renting } \\
\text { and other professional services }\end{array}$ & $\begin{array}{l}6=\text { Intermediations, renting } \\
\text { and other professional } \\
\text { services }\end{array}$ \\
\hline $\begin{array}{l}7=\text { Public administration } \\
\text { and defense }\end{array}$ & $7=$ Real estate, firm services & $\begin{array}{l}7 \text { = Public administration, } \\
\text { defense, instruction, health } \\
\text { and other social services }\end{array}$ \\
\hline $\begin{array}{l}8=\text { Instruction, health } \\
\text { and other social } \\
\text { services }\end{array}$ & $\begin{array}{l}8=\text { Domestic services and other private } \\
\text { services }\end{array}$ & $8=$ Other services \\
\hline $9=$ Other services & $\begin{array}{l}9=\text { Public administration, } \\
\text { defense, instruction, } \\
\text { health and other services }\end{array}$ & \\
\hline
\end{tabular}




\section{REFERENCES}

Alegre J, Mateo S, Pou L. 2010. A latent class approach to tourists' length of stay. Tourism Management 32(3): 555-563.

Alegre J, Pou L. 2006. The length of stay in the demand for tourism. Tourism Management 27(6): 1343-1355.

Artus JR. 1972. An econometric analysis of international travel. International Monetary Fund Staff Papers 19(3): 579-614.

Bell FW, Leeworthy VR. 1990. Recreational Demand by Tourists for Saltwater Beach Days. Journal of Environmental Economics and Management 18(3): 189-205.

Cannon TF, Ford J. 2002. Relationship of demographic and trip characteristics to visitor spending: An analysis of sports travel visitors across time. Tourism Economics 8(3): 263-271.

Crouch GI. 1992. Effect of Income and Price on International Tourism Demand. Annals of Tourism Research 19(4): 643-664.

Crouch GI. 1994a. The Study of International Tourism Demand: A Survey of Practice. Journal of Travel Research 32(4): 41-55.

Crouch GI. 1994b. The Study of International Tourism Demand: A Review of Findings. Journal of Travel Research 33(1): 12-23.

Crouch GI. 1995. A Meta-Analysis of Tourism Demand. Annals of Tourism Research 22(1): 103-118.

Deaton A. 1998. The Analysis of Household Surveys: A Microeconometric Approach to Development Policy. The World Bank.

Decrop A, Snelders D. 2004. Planning The Summer Vacation. An Adaptable Process. Annals of Tourism Research 31(4): 1008-1030.

Downward P, Lumsdon L. 2000. The demand for day-visits: An analysis of visitor spending. Tourism Economics 6(3): 251-261.

Fleischer A, Pizam A. 2002. Tourism constraints among Israeli Seniors. Annals of Tourism Research 29(1): 106-123.

Gokovali U, Bahar O, Kozak M. 2007. Determinants of length of stay: A practical use of survival analysis. Tourism Management 28: 736-746.

Huertas GR. 2006. Estimation of International Tourism Demand Elasticities. ESERP.

Kastenholz E. 2005. Analysis of determinants of visitor, spending for the rural tourist market in North Portugal. Tourism Economics 11(4): 555-569.

Kiefer N. 1988. Economic duration data and hazard functions. Journal of Economic Literature 26: 646-667.

Koenker R, Basset G. 1978. Regression Quantiles. Econometrica 46(1): 33-50.
Li G, Song H, Witt SF. 2005. Recent Developments in Econometric Modeling and Forecasting. Journal of Travel Research 44: 82-99.

Lim C. 1997. Review of International Tourism Demand Models. Annals of Tourism Research 24(4): 835-849.

Lim C. 1999. A Meta-Analytic Review of International Tourism Demand. Journal of Travel Research 37: 273-284.

Machado J, Santos Silva J. 2005. Quantiles for Counts. Journal of the American Statistical Association, American Statistical Association 100: 1226-1237.

Mak J, Moncur J, Yonamine D. 1977. Determinants of visitor expenditures and visitor lenght of stay: A cross-section analysis of US visitors to Hawaii. Journal of Travel Research 15: 5-8.

Mak J, Nishimura E. 1979. The economics of a hotel room tax. Journal of Travel Research 17: 2-6.

Martin CA, Witt SF. 1987. Tourism demand forecasting models: Choice of appropriate variable to represent tourists 'cost of living'. Tourism Management 8(3): 233-246.

Martinez-Garcia E, Raya JM. 2008. Length of stay for low-cost tourism. Tourism Management 29: 1064-1075.

McFadden D. 1981. Econometric models of probabilistic choice. In Structural analysis of discrete data, Manski C, McFadden D (eds). MIT Press: Cambridge; 198-272.

Miranda A. 2006. Qcount: Stata program to fit quantile regression models for count data. Statistical Software Components S456714. Boston College Department of Economics.

Okamura K, Fukushige M. 2010. Differences in travel Objectives between First-time and repeated Tourists: An Empirical Analysis for the Kansai Area in Japan. International Journal of Tourism Research 12: 647-664.

Pestana Barros C, Pinto Machado L. 2010. The length of stay in tourism. Annals of Tourism Research 37(3): 692-706.

Pollak RA. 1969. Conditional demand functions and consumption theory. Quarterly Journal of Economics 83(1): 60-78.

Pollak RA. 1971. Conditional demand functions and the implications of separable utility. Southern Economic Journal 37: 423-433.

Rosenbaum P, Rubin DB. 1983. The central role of the propensity score in observational studies for casual effects. Biometrika 70: 41-50.

Stevens WL. 1950. Fiducial limits of the parameter of a discontinuous distribution. Biometrika 37: 117-129.

Witt SF, Witt CA. 1995. Forecasting Tourism Demand: A Review of Empirical Research. International Journal of Forecasting 11: 447-475. 